\title{
Classification of plant-pathogenic mycoplasma-like organisms using restriction-site analysis of PCR-amplified 16S rDNA
}

\author{
Bernd Schneider, ${ }^{1}$ Ulrich Ahrens, ${ }^{1}$ Bruce C. KirkPatrick ${ }^{2}$ and Erich Seemüller ${ }^{1 *}$ \\ ${ }^{1}$ Biologische Bundesanstalt, Institut für Pflanzenschutz im Obstbau, D-6915 Dossenheim, Germany \\ ${ }^{2}$ Department of Plant Pathology, University of California, Davis, CA 95616, USA
}

(Received 3 June 1992; revised 26 October 1992; accepted 5 November 1992)

\begin{abstract}
A method has been developed to amplify the 16S rRNA gene of plant-pathogenic mycoplasma-like organisms (MLOs) from infected plant material using the polymerase chain reaction (PCR). The procedure is dependent on the presence of a $B c I I$ restriction site in the 16S rDNA of chloroplasts but not in that of the MLOs. This difference permits the specific amplification of the 16S rDNA of the MLOs from BclI-digested total DNA from infected plants using primers from conserved regions of this gene. In this study 16S rDNA was obtained from 52 MLO isolates from herbaceous dicots and monocots as well as woody plants. Digestion of the 16S rRNA genes using AluI endonuclease revealed seven restriction patterns, which were used to group the isolates examined. Group I, which is also characterized by the presence of two $\mathrm{KpnI}$ sites, consisted of 31 isolates, most of which are from herbaceous dicots. Isolates assigned to groups II to VI were mostly from woody plants, while the isolates of group VII were from monocots or obtained from a leafhopper. The restriction patterns varied little within groups; however, four group I isolates and one group IV isolate differed slightly from the typical patterns of these groups as a result of a deletion or a slight shift of one restriction site. The groupings uncovered by $A l u I$ restriction were also obtained by digesting the 16S rDNA with RsaI endonuclease. However, some atypical patterns were observed within group $V$ isolates. The groups described on the basis of restriction digest data were supported by sequence analysis. With one exception, the $16 \mathrm{~S}$ rDNA of isolates within the same group exhibited 97.8 to $99.5 \%$ homology while those of different groups showed 89.6 to $92.0 \%$ homology.
\end{abstract}

\section{Introduction}

Mycoplasma-like organisms (MLOs) are nonculturable, parasitic prokaryotes of the class Mollicutes associated with diseases of several hundred plant species (McCoy $e t$ al., 1989). Until recently, differentiation and characterization was mainly based on host range and the symptoms induced in natural hosts and in the experimental host Catharanthus roseus (L.) G. Don (periwinkle) (Marwitz, 1990). However, with the introduction of serological and nucleic acid hybridization methods into plant mycoplasmology, more reliable and specific means are available to characterize MLOs. The development of techniques to obtain MLO DNA from infected plants and insect vectors and the cloning of MLO DNA have greatly enhanced this work. A number

\footnotetext{
*Author for correspondence. Tel. 49621185238 ; fax 496221 861222.
}

Abbreviation: MLO, mycoplasma-like organism. of recent papers on dot and Southern hybridization has contributed to our better understanding of the relatedness of the MLOs (Bertaccini et al., 1990; Bonnet et al., 1990; Lee \& Davis, 1988; Lee et al., 1990; Kuske et al., 1991). Based on Southern hybridization with a DNA fragment of an MLO associated with aster yellows, a differentiation between organisms inducing decline symptoms and those causing floral virescence has been proposed (Kuske et al., 1991). Although several organisms have been differentiated using these methods they are limited by the fact that undefined DNA fragments have been used as probes.

In contrast to undefined genomic DNA fragments, the $16 \mathrm{~S}$ rRNA gene is a universal character which provides valuable molecular information on MLOs. This gene shows regions which are highly conserved among the prokaryotes while other regions show considerable variation, thus permitting phylogenetic and taxonomic studies (Stackebrandt, 1991). Recently, 16S rRNA sequences have been used for the phylogenetic analysis and classification of culturable mollicutes (Weisburg et al., 1989) and to elucidate the phylogeny of two MLOs (Lim 
Table 1. Origin and source of the MLO isolates and the symptoms they induce in periwinkle

\begin{tabular}{|c|c|c|c|c|}
\hline $\begin{array}{l}\text { MLO } \\
\text { code }\end{array}$ & Origin & $\begin{array}{c}\text { Country/ } \\
\text { state }\end{array}$ & Source* & $\begin{array}{c}\text { Symptom } \\
\text { group } \dagger\end{array}$ \\
\hline AAY & American aster yellows & Florida & 1 & A \\
\hline ACLR & Apricot chlorotic leaf roll & Spain & 2 & A \\
\hline AKV & Virescence of Aquilegia alpina L. & Germany & 3 & A \\
\hline AP & Apple proliferation & Italy & $4 a$ & $\mathrm{D}$ \\
\hline ASHY & Ash yellows & New York & 5 & D \\
\hline AT & Apple proliferation & Germany & $3 \mathrm{a}$ & D \\
\hline AV2192 & Aster yellows & Germany & 3 & B \\
\hline AV2226 & Aster yellows & Germany & 3 & B \\
\hline AYW & Eastern American aster yellows & New Jersey & 6 & B \\
\hline BGWL & Bermudagrass white leaf & Thailand & 7 & \\
\hline BVK & Leafhopper-borne (Psammotettix cephalotes) & Germany & 8 & D \\
\hline COL & Latent in Cuscuta odorata Ruiz et Pav. & $?$ & $8 \mathrm{a}$ & $\mathrm{D}$ \\
\hline CVA & Leafhopper-borne (species not determined) & Germany & 8 & A \\
\hline CVB & Leafhopper-borne (species not determined) & Germany & 8 & A \\
\hline CVL & Catharanthus virescence & Peru & 9 & A \\
\hline CVT & Catharanthus virescence & Thailand & 7 & A \\
\hline DEV & Virescence of a Delphinium hybrid & Germany & $3 \mathrm{~b}$ & $\mathrm{C}$ \\
\hline DIV & Virescence of Diplotaxis erucoides (L.) DC & Spain & 10 & B \\
\hline EAY & Aster yellows & Germany & 3 & B \\
\hline EY & Elm yellows & New York & $5 a$ & $\mathrm{D}$ \\
\hline FDI & Flavescence dorée & Italy & 4 & A \\
\hline GVX & Green Valley strain of X-disease & California & 11 & $\mathrm{D}$ \\
\hline HYDP & Hydrangea phyllody & Belgium & 12 & A \\
\hline KV & Clover phyllody & Germany & 3 & A \\
\hline KVE & Clover phyllody & England & 11 & A \\
\hline MOL & Molière's disease of cherry & France & 13 & $\mathbf{A}$ \\
\hline OAY & Virescence of Oenothera hookeri & USA & 14 & \\
\hline PARM & Apricot decline & Germany & 7 & \\
\hline PER & Peach decline & Italy & 15 & A \\
\hline PLN-V6 & Plum leptonecrosis & Italy & 4 & A \\
\hline PPER & Peach decline & Germany & 7 & \\
\hline PRIVA & Virescence of primrose (Primula sp.) & Germany & $3 c$ & $\mathrm{C}$ \\
\hline PRIVB & Virescence of primrose (Primula sp.) & Germany & $3 \mathrm{c}$ & D \\
\hline PRIVC & Virescence of primrose (Primula sp.) & Germany & $3 \mathrm{c}$ & A \\
\hline PSER & Decline of Prunus serrulata Lindl. & Germany & 7 & \\
\hline PVM & Virescence of Plantago coronopus $\mathrm{L}$. & Germany & 3 & B \\
\hline PVW & Virescence of Plantago major $\mathrm{L}$. & Germany & 8 & $\mathrm{C}$ \\
\hline PYLR & Peach yellow leaf roll & California & 11 & $\mathrm{D}$ \\
\hline RCAE & Rubus stunt of $R$. caesius $\mathrm{L}$. & Germany & 7 & \\
\hline RV & Rape virescence & France & 16 & B \\
\hline SAFP & Safflower phyllody & Israel & 17 & A \\
\hline SAS & Sandal spike & India & 18 & A \\
\hline SAY & American western aster yellows & California & 19 & A \\
\hline SBB & Big bud of Solanum marginatum $\mathrm{L}$. & Ecuador & $3 d$ & A \\
\hline SCWL & Sugarcane white leaf & Thailand & 7 & \\
\hline STOL & Stolbur of Capsicum annuum $\mathrm{L}$. & Croatia & 20 & A \\
\hline STOLF & Stolbur of Lycopersicon esculentum Mill. & France & 21 & A \\
\hline SUNHP & Sunhemp phyllody & Thailand & 7 & A \\
\hline TBB & Tomato big bud & Australia & 11 & A \\
\hline ULW & Witches' broom of Ulmus carpinifolia Gled. & France & 22 & D \\
\hline VAC & Witches' broom of Vaccinium myrtillus $\mathrm{L}$. & Germany & $3 e$ & D \\
\hline WX & Western X-disease & California & 23 & \\
\hline
\end{tabular}

*Collected and/or transmitted to periwinkle or Coleus blumei, or provided by: 1, R. E. McCoy, University of Florida, Fort Lauderdale, USA (via 3); 2, G. Llacer, IVIA, Moncada-Valencia, Spain (via 13); 3, R. Marwitz, Biologische Bundesanstalt, Berlin, Germany (3a Marwitz et al., 1974, 3b Marwitz \& Petzold, 1976, 3c Marwitz \& Petzold, 1983, 3d Marwitz et al., 1979, 3e Marwitz et al., 1987); 4, L. Carraro, Università degli Studi, Udine, Italy (4a Carraro et al., 1988); 5, W. A. Sinclair, Cornell University, Ithaca NY, USA (5a Sinclair et al., 1976); 6, R. F. Whitcomb, USDA-ARS, Beltsville MD, USA (via 11); 7, collected by the authors; 8, W. Heintz, Biologische Bundesanstalt, Dossenheim, Germany (8a Heintz, 1989); 9, C. E. Fribourg, International Potato Center, Lima, Peru (via 3); 10, P. Moreno, IVIA, Moncada-Valencia, Spain (Moreno et al., 1985) (via 3); 11, M. F. Clark, Horticulture Research International, East Malling, UK; 12, W. Welvaert, Rijksuniversiteit, Gent, Belgium (Welvaert et al., 1975) (via 3); 13, F. Dosba, INRA, Bordeaux, France; 14, B. B. Sears, MSU, East Lansing, USA (Sears \& Klomparens, 1989); 15, A. Ragozzino, Università di Napoli-Portici, Naples, Italy (via 13); 
\& Sears, 1989; Kuske \& Kirkpatrick, 1992). Both sequence and restriction enzyme analysis of $16 \mathrm{~S}$ rDNA have been used in taxonomic studies on mollicutes (Göbel et al., 1987; Laigret et al., 1990; Taschke et al., 1990) and other prokaryotes (Grimont \& Grimont, 1986; Bouvet et al., 1991; Gurtler et al., 1991). The study of the 16S rRNA gene is greatly facilitated by the application of polymerase chain reaction (PCR) technology using primers that allow amplification of prokaryote $16 \mathrm{~S}$ rDNA. Here we report a method which amplifies the 16S rRNA gene from MLOs and can be used to group them on the basis of restriction enzyme analysis of $16 \mathrm{~S}$ rDNA.

\section{Methods}

Sources of MLOs and MLO $16 S$ rDNA sequences. Sources of the MLOs examined and the codes used to describe them are listed in Table 1. Isolate EAY was maintained in the greenhouse in Coleus blumei Benth. by cuttings. PARM, PPER, PSER and RCAE were obtained from diseased apricot, peach, flowering cherry (Prunus serrulata Lindl.) and Rubus caesius L., respectively, grown in the experimental field of the Dossenheim institute. BGWL and SCWL were obtained from diseased bermudagrass and sugarcane, respectively, collected near Bangkok, Thailand. All other isolates were maintained in an insectproof greenhouse in periwinkle by graft transmission. With the exception of the naturally infected isolates, CVL and CVT, the periwinkle-maintained MLOs were originally transmitted to this host with Cuscuta spp. bridges or by leafhoppers. The symptoms induced in periwinkle are indicated in Table 1. 16S rDNA sequences of the Oenothera (OAY-) (Lim \& Sears, 1989) and western aster yellows (SAY-) MLOs (Kuske \& Kirkpatrick, 1992) were included in the study for comparison.

Other prokaryotes. Isolates of Agrobacterium tumefaciens (strain At 1), Clavibacter michiganensis (strain C 2140), Erwinia amylovora (strain Ea. 6/6), and Xanthomonas campestris (strain Xc 314) (all obtained from W. Zeller, Biologische Bundesanstalt, Dossenheim) were grown on nutrient glycerol agar slants. Escherichia coli (strain XL1 blue, Stratagene) and Spiroplasma citri (strain R8A2, obtained from C. Saillard, INRA Bordeaux, France) were cultivated in LB medium (Maniatis at al., 1982) and BSR medium (Bové \& Saillard, 1979), respectively. Overnight growth from the cultures on solid media suspended in water and similar-aged liquid cultures of $E$. coli and $S$. citri were used without further treatment for in vitro amplification of $16 \mathrm{~S}$ rDNA as described below.

PCR amplification. Five different primers from conserved regions of the 16S rRNA gene were used. The pair fD1 and rP1 (Weisburg et al.,
1991) primed proximal to the $5^{\prime}$ and $3^{\prime}$ termini, allowing the amplification of nearly the entire $16 \mathrm{~S}$ rRNA gene. The three internal primers consisted of the forward primer fA extending from position 759 to 778 of the OAY-MLO (Lim \& Sears, 1989), the reverse primer rA extending from position 1316 to 1297 of the same organism (Ahrens \& Seemüller, 1992), and the reverse primer $\mathrm{rC}$ which is complementary to primer $f A$.

DNA from healthy and diseased plants was obtained by using an MLO enrichment procedure as described previously (Ahrens \& Seemüller, 1992). Five microlitres of such DNA preparations were digested with $5 U$ of $B c l l$ restriction endonuclease (Amersham) in a total volume of $20 \mu \mathrm{l}$. Five microlitres of the digest or of bacterial suspension were used to amplify DNA in a $50 \mu$ l reaction containing $125 \mu \mathrm{M}$ of the four dNTPs, $0.5 \mu \mathrm{M}$ of each of the primers, and $1 \mathrm{U}$ of Taq polymerase (Boehringer-Mannheim). PCR conditions consisted of 30 cycles of $30 \mathrm{~s}$ at $95^{\circ} \mathrm{C}, 30 \mathrm{~s}$ at $50^{\circ} \mathrm{C}$, and $60 \mathrm{~s}$ at $72^{\circ} \mathrm{C}$, plus one additional cycle with a 4 min chain elongation. After amplification, $5 \mu l$ of the product was digested with $B c I I$ as described above and was then separated by electrophoresis in a horizontal $1 \%(\mathrm{w} / \mathrm{v})$ agarose gel in TAE buffer ( $40 \mathrm{~mm}$-Tris/acetate, $1 \mathrm{~mm}$-EDTA, $\mathrm{pH} \mathrm{8.0)}$ ). From the band containing the desired 16S rDNA some material was removed from the gel with a hypodermic syringe and was, without further purification, amplified again as described above. The purity of the final product was examined by another $B c l$ digestion followed by agarose gel electrophoresis. 16S rDNA of healthy plants was amplified without $B c l$ digestion. All amplifications were performed using a Thermocycler 60 (bio-med).

Restriction digest and gel electrophoresis. The final amplification products were digested with $A l u \mathrm{I}, R s a \mathrm{I}, E c o \mathrm{RI}$ or $K p n \mathrm{I}$, following the manufacturer's instructions (Amersham). Five microlitres of AluI and $R s a I$ digests were resolved on vertical 5 or $8 \%(\mathrm{w} / \mathrm{v})$ polyacrylamide gels in TBE buffer $(89 \mathrm{~mm}$-Tris/borate, $89 \mathrm{~mm}$-boric acid, $2 \mathrm{~mm}$ EDTA, pH 8.0). The EcoRI and KpnI digests were separated by electrophoresis in $1 \%(\mathrm{w} / \mathrm{v})$ agarose as previously described. The DNA was visualized under UV light after staining with ethidium bromide.

DNA sequencing. PCR-amplified 16S rDNAs from the AAY-, ACLR-, ASHY-, AT-, EY-, PPER- and ULW-MLOs were cloned in Bluescript M13 + (Stratagene) using standard procedures; ligation was performed according to Marchuk et al. (1991). One strand of the cloned 16S rDNA was sequenced with the Sequenase kit (US Biochemical) following the manufacturer's instructions. Two universal primers priming near the multiple cloning site (T3 and SK, Stratagene), one internal primer designed by Lane et al. (1985) extending from position 532 to 515 of the 16S rRNA gene of $E$. coli, another reverse primer designed by F. Laigret (personal communication, position 1068 to 1049 of $E$. coli), and the two internal reverse primers $\mathrm{rA}$ and $\mathrm{rC}$ described previously were used.

Analysis of data. Sequences of the 16S rRNA genes of the following organisms were compared by multiple alignment using the Clustal program (Higgins \& Sharp, 1988): OAY- (EMBL/GenBank accession

15, G. Marchoux, INRA, Avignon-Montfavet, France (Marchoux \& Giannotti, 1971) (via 3); 17, M. Klein, Volcani Center, Bed Dagan, Israel (Klein, 1970) (via 3); 18, J. Dijkstra, Agricultural University, Wageningen, Netherlands (Dijkstra \& Lee, 1972) (via 3); 19, B. C. Kirkpatrick, University of California, Davis, USA (Kuske \& Kirkpatrick, 1992); 20, D. Sutic, University of Zagreb, Croatia (via 3); 21, M.-T. Cousin, INRA, Versailles, France; 22, G. Morvan, INRA, Avignon-Montfavet, France (via 13); 23, D. D. Jensen, University of California, Berkeley (Jensen, 1986).

$\dagger$ According to the predominant symptoms in periwinkle: A, virescence, phyllody (typical for clover phyllody and stolbur); B, virescence, phyllody, elongated and etiolated internodes (typical aster yellows symptoms); C, small and faintly coloured flowers, elongated and etiolated internodes (atypical aster yellows symptoms); D, reduced flower size, leaf and flower malformations, no virescence, phyllody or elongated and etiolated internodes ('decline MLOs'). 
no. M30970), WX- (L04682), SAY- (M86340), AAY- (X68373), ACLR- (X68338), ASHY- (X68339), AT- (X68375), EY- (X68377), PPER- (X68374) and ULW- (X68376) MLOs, and S. citri (M23942). Analysis for the presence of BclI, AluI and RsaI restriction sites was performed with 16S rDNA of Spiroplasma apis (M23937), Mycoplasma hominis (M2447), M. hyopneumoniae (Y00149), M. capricolum (X00921), Acholeplasma laidlawii (M23932), Anaeroplasma abactoclasticum (M25050), E. coli (V00348), and Clostridium innocuum (M23732). The 16S rDNA of the chloroplasts of Glycine max (X06428), Nicotiana tabacum (V00165), Pisum sativum (M30826), Spinacea oleracea (101440) and Sinapis alba (X04182) were also included in restriction site analysis. All sequences of the culturable prokaryotes and the chloroplasts, as well as those of the OAY-and SAY-MLOs, were available in the EMBL Data Library, Heidelberg, Germany.

\section{Results}

\section{Amplification of $16 S$ rDNA}

Sequence comparisons with the 16S rRNA genes of the OAY-, WX-, AT- and AAY-MLOs and the chloroplasts examined revealed the presence of a $B c l I$ restriction site in the chloroplasts but not in the gene of the MLOs. To obtain a specific PCR amplification of the 16S rDNA of the MLOs, the DNA from infected plants was digested with $B c l$ I before amplification. As the digest was usually incomplete, the amplification products were also $B c I I-$ restricted. Gel electrophoresis resolved one fragment approximately $1500 \mathrm{bp}$ in size representing the $16 \mathrm{~S}$ rRNA gene of the MLOs. The cleaved 16S rDNA of the chloroplasts appeared as two fragments approximately 800 and $700 \mathrm{bp}$ in length.

\section{Restriction and sequence analysis}

The 52 isolates examined were grouped according to the presence of $A l u \mathrm{I}$ and $R s a \mathrm{I}$ restriction sites. All sites of groups I to VI of which complete (AAY, ACLR, AT, OAY, PPER, SAY, WX) or partial (ASHY, EY, ULW) sequences of representative isolates were available could be determined. With the exception of the RsaI sites yielding very small fragments, all sites of group VII were also determined using internal primers. The sizes of the amplified rDNA sequences and of the restriction fragments differed slightly due to small deletions or insertions. However, the position of the restriction sites could be determined by aligning the sequences with the analogous sequence of the OAY-MLO to which all MLO positions given in this paper correspond.

Restriction digestion of the amplified 16S rDNA with AluI revealed seven different profiles among the MLO isolates (Figs 1 and 2), which were used to divide the isolates into seven major groups (Table 2). Group I is the largest and includes 31 isolates. With the exception of the periwinkle-maintained isolates HYDP, MOL, SAS and PER from woody hosts, they all originate from her- baceous dicots or were obtained from leafhoppers (Table 1). All isolates of group I showed five restriction sites at positions $\mathrm{a}, \mathrm{d}, \mathrm{e}, \mathrm{f}$ and $\mathrm{g}$ (Fig. 1). Group I contains isolate MOL and the stolbur-type isolates STOL, STOLF and TBB, which differ from the other group members by a

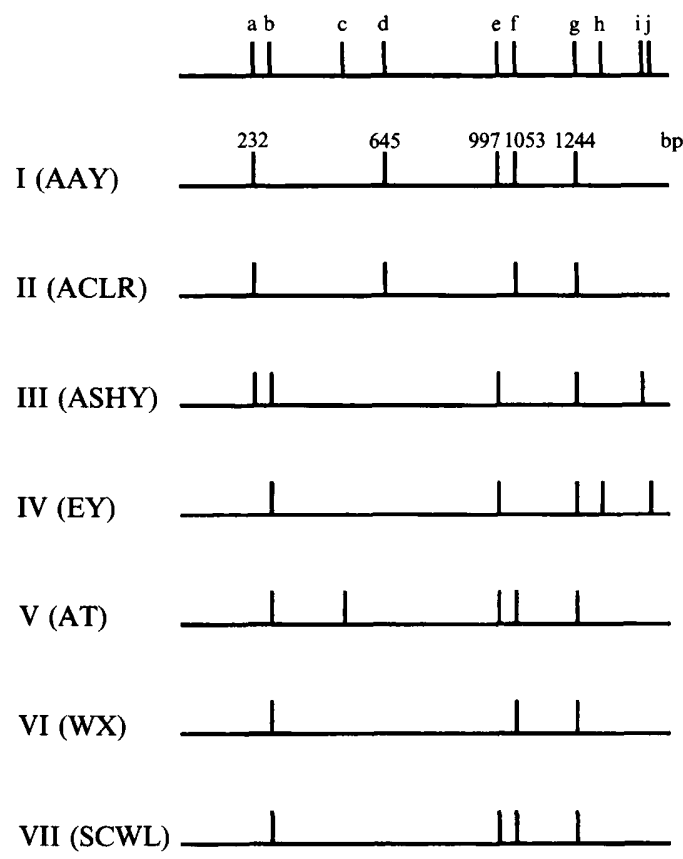

Fig. 1. AluI restriction map of $16 \mathrm{~S}$ rDNA depicting the seven (I-VII) different restriction profiles that occur among the MLOs examined. Representative isolates of the seven groups are given in parentheses (see Table 1 for MLO code). The figures given in group I correspond to the sequence positions of the OAY-MLO.

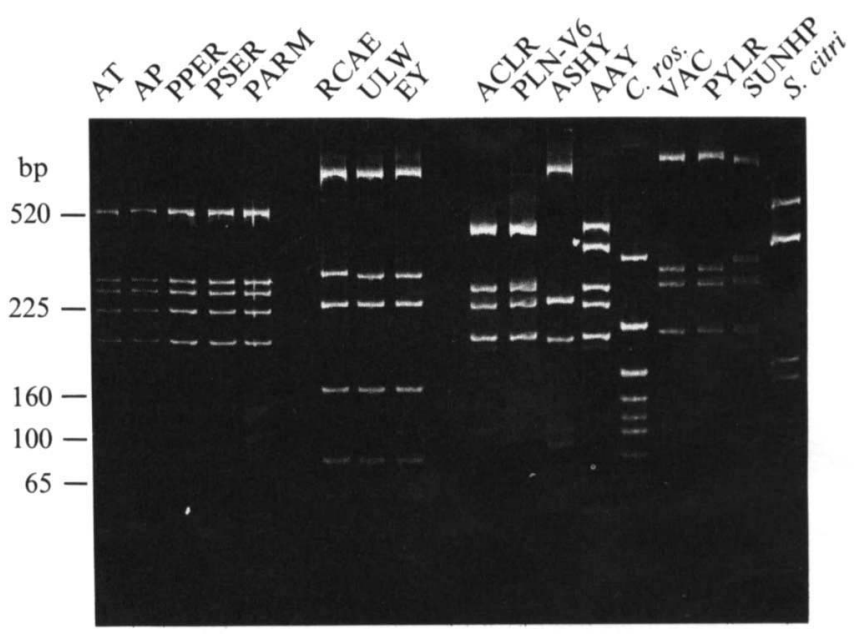

Fig. 2. AluI restriction profiles of $16 \mathrm{~S}$ rDNA from MLOs representing six of the seven groups established. AT to PARM, group I; RCAE to EY, group IV; ACLR and PLN-V6, group II; ASHY, group III; AAY, group I; VAC to SUNHP, group VI; $C$. ros., healthy periwinkle; $S$. citri, Spiroplasma citri. See Table 1 for MLO codes. 


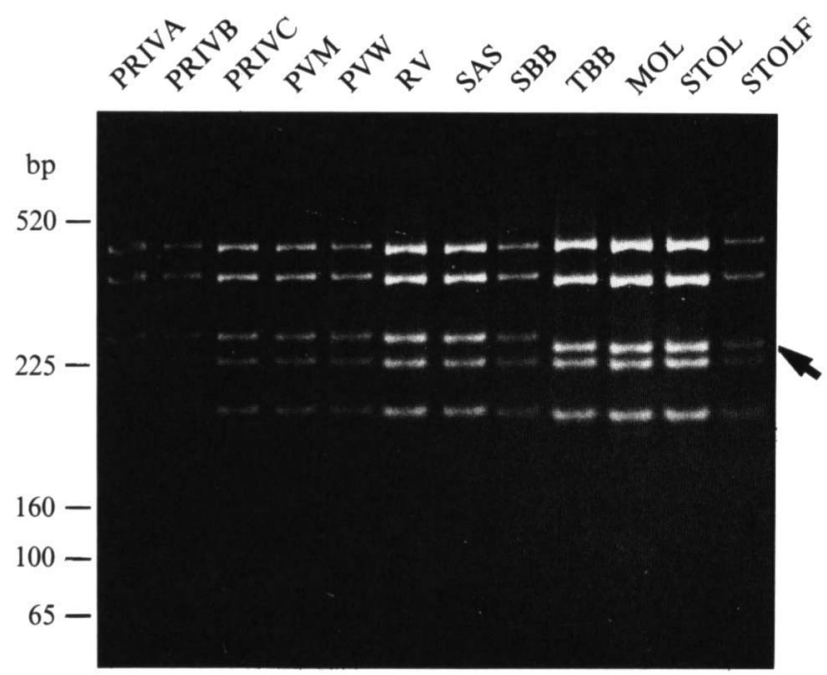

Fig. 3. AluI restriction profiles of $16 \mathrm{~S}$ rDNA of MLO isolates of group I showing that one fragment (arrow) of the isolates TBB to STOLF is slightly smaller than those of the typical isolates PRIVA to SBB. See Table 1 for MLO codes.

Table 2. Grouping of the MLO isolates examined based on restriction analysis of AluI- and RsaI-digested $16 \mathrm{~S}$ $r D N A$

\begin{tabular}{|c|c|c|c|}
\hline \multirow[b]{2}{*}{ Group } & \multirow[b]{2}{*}{ Typical isolates* } & \multicolumn{2}{|c|}{$\begin{array}{l}\text { Group members showing atypical } \\
\text { results }\end{array}$} \\
\hline & & AluI digest & RsaI digest \\
\hline I & $\begin{array}{l}\text { AAY, AKV, AV2192, } \\
\text { AV2226, AYW, COL, } \\
\text { CVA, CVB, CVL, CVT, } \\
\text { DEV, DIV, EAY, } \\
\text { HYDP, KV, KVE, OAY, } \\
\text { PER, PRIVA, PRIVB, } \\
\text { PRIVC, PVM, PVW, } \\
\text { RV, SAFP, SAS, SAY, } \\
\text { SBB }\end{array}$ & $\begin{array}{l}\text { MOL, STOL, } \\
\text { STOLF, TBB }\end{array}$ & $\begin{array}{l}\text { MOL, STOL, } \\
\text { STOLF, TBB }\end{array}$ \\
\hline II & ACLR, PLN-V6 & & \\
\hline III & ASHY & & \\
\hline $\begin{array}{l}\text { IV } \\
\text { V }\end{array}$ & $\begin{array}{l}\text { EY, RCAE, ULW } \\
\text { AP, AT }\end{array}$ & & $\begin{array}{l}\text { PARM, PPER, } \\
\text { PSER } \dagger\end{array}$ \\
\hline VI & $\begin{array}{l}\text { FDI, GVX, PYLR, } \\
\text { VAC, WX }\end{array}$ & SUNHP & SUNHP \\
\hline VII & BGWL, BVK, SCWL & & \\
\hline
\end{tabular}

* See Table 1 for MLO code.

$\dagger$ AluI restriction profiles of these isolates are identical to that of the AP- and AT-MLO.

slightly shorter $3^{\prime}$ fragment (Fig. 3). Restriction analysis of a fragment amplified with the internal primers $f A$ and $\mathrm{rA}$ revealed that these isolates have a deletion of estimated size $10 \mathrm{bp}$ near restriction site $\mathrm{g}$.

Most isolates of groups II to VI were from woody hosts (Table 1). Group II differs from group I by the lack of $A l u \mathrm{I}$ restriction site e. The ASHY-MLO, which
Table 3. Rsal restriction maps of PCR-amplified $16 S$ rDNA of MLOs representing the seven groups evidenced by AluI digestion

\begin{tabular}{lcccccccc}
\hline \hline & \multicolumn{8}{c}{ Groups and representative isolates: } \\
\cline { 2 - 8 } Site and & I & II & III & IV & V & VI & VII \\
position* & AAY & ACLR ASHY & EY & AT & WX & SCWL \\
\hline k & 425 & + & - & - & - & $(-)$ & + & - \\
l & 482 & + & + & - & - & - & + & - \\
m & 819 & + & + & + & + & + & + & + \\
n & 843 & - & - & + & + & - & + & $?$ \\
o & 863 & + & + & + & + & + & + & $?$ \\
p & 879 & + & + & + & + & + & - & $?$ \\
q & 883 & + & + & + & + & + & + & + \\
r & 956 & + & + & - & + & - & - & - \\
s & 1381 & + & + & + & + & + & + & + \\
\hline \hline
\end{tabular}

*Corresponding to the OAY-MLO (Lim \& Sears, 1989). +, - , restriction site present or missing, respectively; ?, site could not be determined because restriction fragments too small; $(-)$ site present in isolates PARM, PPER, and PSER of Group V.

represents group III, lacks restriction sites $d$ and $f$ but shows restriction sites $b$ and i. Groups IV to VII lack restriction site a. In addition, group IV lacks restriction sites $\mathrm{d}$ and $\mathrm{f}$ and is the only group with restriction sites $\mathrm{h}$ and $\mathrm{j}$. Restriction site $\mathrm{c}$ occurs in group $\mathrm{V}$ only. Group VI is characterized by the presence of only three AluI restriction sites, at positions $b, f$ and $g$ (Figs 1 and 2). The SUNHP-MLO differs, probably due to a downstream shift of restriction site $b$, from the other isolates of group VI by a smaller fragment between sites $b$ and $f$ and $a$ larger $5^{\prime}$ fragment. Group VII (data not shown in Fig. 2) includes two MLOs from the monocot hosts sugarcane and bermudagrass as well as the leafhopper-borne isolate BVK. With the exception of the missing restriction site $c$, this group shows the same pattern as group $\mathrm{V}$. The only AluI restriction site common to all the MLOs is $\mathrm{g}$ (Fig. 1).

$R s a$ I restriction analysis recovered identical groupings to those revealed by AluI digestion (Tables 2 and 3, Fig. 4). With the former enzyme, a total of nine restriction sites ( $\mathrm{k}$ to $\mathrm{s}$ ) were found, of which the three at positions $\mathrm{m}$, $\mathrm{q}$ and $\mathrm{s}$ were common to all MLOs examined. The isolates of group I have eight restriction sites and show the same profile. As with the patterns obtained after $A l u \mathrm{I}$ digestion, isolate MOL and the stolbur-type isolates STOL, STOLF and TBB differ from the other MLOs of this group by a deletion near the $3^{\prime}$ terminus, resulting in a shorter $425 \mathrm{bp}$-fragment between sites $\mathrm{r}$ and $\mathrm{s}$. The isolates within the groups II and IV, respectively, were homogeneous. Isolate ASHY (group III) differs from group IV by the lack of restriction site $r$. In group $V$, the Prunus isolates PARM, PPER and PSER differ from the apple isolates AP and AT by an additional restriction site at position $\mathrm{k}$. In group VI, all isolates show the same 


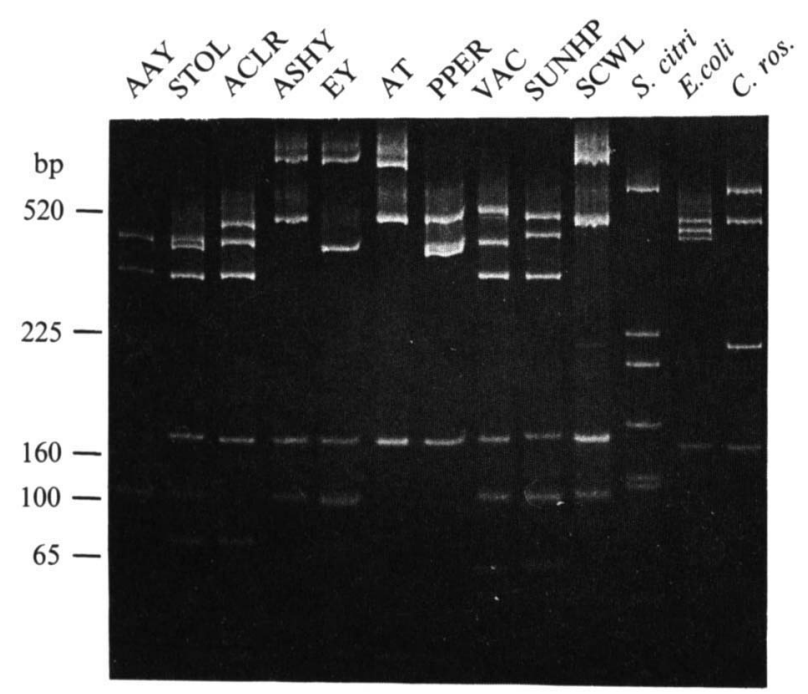

Fig. 4. RsaI restriction profiles of 16S rDNA from MLOs representing the seven groups established. AAY and STOL, group I (AAY has two fragments $425 \mathrm{bp}$ in length while for STOL one of them is slightly smaller); ACLR, group II; ASHY, group III; EY, group IV; AT and PPER, group V (PPER has an additional restriction site); VAC and SUNHP, group VI (SUNHP varies in the two uppermost fragments); SCWL, group VII; C. ros., healthy periwinkle. See Table 1 for MLO codes.

Table 4. Sequence homology (\%) of the $16 S \mathrm{rDNA}$ of various MLOs

See Table 1 for MLO code.

\begin{tabular}{|c|c|c|c|c|c|c|}
\hline & OAY & SAY & ACLR & $\mathrm{AT}$ & PPER & WX \\
\hline AAY & $98 \cdot 4$ & 98.7 & 97.9 & $90 \cdot 0$ & $91 \cdot 4$ & 89.6 \\
\hline OAY & & 99.5 & $98 \cdot 4$ & 92.0 & $92 \cdot 6$ & $90 \cdot 7$ \\
\hline SAY & & & $98 \cdot 0$ & 90.4 & $91 \cdot 4$ & $90 \cdot 0$ \\
\hline ACLR & & & & $90 \cdot 1$ & $90 \cdot 9$ & 90.0 \\
\hline AT & & & & & $97 \cdot 8$ & 90.6 \\
\hline PPER & & & & & & 90.9 \\
\hline
\end{tabular}

profile except SUNHP, which showed slight differences in the AluI digestion and has a $5^{\prime}$ fragment that is approximately $15 \mathrm{bp}$ longer than that of the other isolates while the fragment between position $\mathrm{q}$ and $\mathrm{s}$ is shorter to the same degree. SCWL shows the same major fragments as AT and AP. However, the position of $R s a \mathrm{I}$ sites at the Rsa site aggregation in the middle of the gene could not be determined with the electrophoresis methods used.

All isolates showed a unique $E c o$ RI restriction site in the 16S rDNA at position 669 of the OAY-MLO. Also, a unique $N r u$ I site at position 1340 was detected in all organisms from which sequencing data were available. Isolates of group I showed two KpnI sites at positions 488 and 959 which were absent in the other groups. The only exception was CVB (group I), which has one KpnI site at either position 488 or 959 . In addition, the two organisms of group II have one KpnI site at position 959.

The differences between the groups and the homogeneity within individual groups was also shown by comparing the homology of the total sequences of the amplified rRNA genes (Table 4). Thus, isolates of the same group exhibit 98.4 to $99.5 \%$ homology while those of different groups usually differ by about $10 \%$. However, isolate ACLR of group II is highly homologous to the group I MLOs. Isolate PPER, which produced an atypical $R s a I$ restriction profile, showed a homology of $97.8 \%$ with AT-MLO, another group V isolate.

Sequence analysis showed that all the walled and wallless prokaryotes examined differ in the AluI and RsaI restriction patterns of the 16S rDNA from those of the MLOs included in this study. Also, the 16S rRNA genes of the plant pathogenic bacteria Xanthomonas campestris, Erwinia amylovora, Clavibacter michiganensis and Agrobacterium tumefaciens showed different profiles than the MLOs. The RsaI patterns of E. coli and $S$. citri are shown in Fig. 4.

In both the $A l u \mathrm{I}$ and $R s a \mathrm{I}$ restriction profiles of a number of MLOs, a DNA fragment approximately 100 bp in size became evident which is not part of the $16 \mathrm{~S}$ rRNA gene (Figs 2 and 4). Its origin remains obscure.

\section{Discussion}

The 16S rRNA gene is the most widely used sequence in taxonomic studies on the prokaryotes. However, the study of $16 \mathrm{~S}$ rRNA sequences in MLOs presents problems as they have not, as yet, been cultured in vitro. With the method described in this paper, 16S rDNA of the MLOs can readily be obtained by PCR amplification without recourse to in vitro cultivation. Examination of the amplified fragment by restriction and sequence analysis showed that it represents the authentic $16 \mathrm{~S}$ rDNA of the MLOs and not the gene of other plantassociated prokaryotes or chloroplasts. Also, there is strong evidence that the amplified sequence was from one organism or at least from organisms of the same group because the restriction patterns of the isolates assigned to a group or a subgroup were uniform and there was no indication of mixed patterns. However, the presence of a second organism from a different group cannot be excluded, if it was present in low numbers relative to the organism that was amplified. The results obtained do not give information on the number of rRNA operons. The fact that $16 \mathrm{~S}$ rDNA of any MLO would have been amplified with the primers used and that the restriction patterns were typical for one rRNA gene indicates that the MLOs examined have either only one rRNA operon or the copies of the 16S rRNA gene of 
one organism yield similar restriction patterns. The culturable mollicutes have either one or two rRNA operons (Razin, 1989), and two occur in the OAY-MLO (Lim \& Sears, 1989).

The MLOs examined originate from four continents and are associated with diseases of woody plants and of herbaceous monocots and dicots. In addition, the organisms induce very different symptoms in periwinkle. On the basis of the restriction patterns of the 16S rDNA, the organisms included in this study could be divided into seven groups. About $60 \%$ of the isolates were assigned to group I, in which MLOs from all four symptom groups are represented (Table 1). Most of these MLOs were from herbaceous dicots and include the agents of aster yellows, clover phyllody, periwinkle virescence, and stolbur and/or big bud of solanaceous plants.

There are results from hybridization experiments which support the interrelatedness of the obviously diverse MLOs of group I. B. Schneider (unpublished results) hybridized Southern blots of DNA from most of the organisms included in this study with chromosomal DNA probes of the AAY-MLO. Under moderate stringency conditions these probes hybridized to most of the MLOs included in group I. Kuske et al. (1991) found homology between DNA probes from an AY-MLO and the stolbur isolate STOL as well as several isolates that induce AY symptoms in periwinkle. Also, probes from another AY-MLO cross-hybridized with DNA of the tomato big bud (BB)-MLO and of an MLO causing virescence in $C$. roseus (Lee \& Davis, 1988). On the other hand, DNA fragments of the BB-MLO hybridized with DNA of the MLOs associated with clover phyllody and a virescence of $C$. roseus (Lee et al., 1990).

In contrast to group I, the MLOs within the other groups are more uniform with regard to symptom induction and host range. The two isolates of group II (ACLR and PLN-V6) are considered to be identical or closely related because they induce similar symptoms in periwinkle and showed close relationship in Southern hybridization experiments (Ahrens et al., 1992). The ASHY - and the EY-MLOs induce similar symptoms in periwinkle but showed some differences in the restriction patterns of $16 \mathrm{~S}$ rDNA and were, for that reason, assigned to different groups (III and IV). This distinction appears appropriate as Bertaccini et al. (1990) and Davis et al. (1992) found little cross-hybridization between these two isolates. Probes from the ASHY- and the EY-MLO did not cross-hybridize to DNA of the MLOs associated with AY, BB, and virescence of $C$. roseus. The ULWMLO, the second elm isolate of group IV, causes similar symptoms in periwinkle and had Southern hybridization restriction patterns identical to the EY-MLO (Mäurer \& Seemüller, 1992).
Group V comprises European fruit isolates. DNA probes from the apple proliferation isolate AT crosshybridized with DNA of isolate AP and with those of the three stone fruit isolates PARM, PPER and PSER (Ahrens et al., 1992). However, the hybridization profiles of the stone fruit isolates were different from that of the apple MLOs, as observed by $R s a \mathrm{I}$ restriction analysis in this study. Genomic probes from the AT-MLO did not hybridize with isolates of group I, II, VI and VII (Bonnet et al., 1990; B. Schneider, unpublished results). The isolates of group VI are more heterogeneous than those of groups II to V, which were all obtained from woody plants and induce, depending on the group, either virescence or non-virescence symptoms in periwinkle. The MLOs assigned to group VI were from woody and herbaceous hosts and cause virescence or non-virescence diseases. The relationship of the group VI MLOs to the virescence MLOs was also shown by Southern blot hybridization experiments in which genomic probes from the VAC-MLO hybridized with DNA of the ACLR-and the PLN-V6-MLOs as well as with several isolates of group I which mostly induce virescence symptoms (Ahrens et al., 1992; B. Schneider, unpublished results). Group VII, includes the only MLOs examined (SCWL and BGWL) that are known to originate from monocots.

Although the taxonomic rank of the seven groups established is not clear, their complexity differs considerably. The small groups II to V and VII include only one organism or a few closely related MLOs. These groupings are supported by hybridization results, host range, and the symptoms induced. The MLOs of group VI are more heterogeneous and remain to be further differentiated. This is especially true of isolate SUNHP, which may be sufficiently different from the other group VI MLOs to form a subgroup or a group of its own. The situation in group I is more complex because it includes organisms which can be distinguished by their association with diseases such as aster yellows, clover phyllody, sandal spike, or stolbur. Thus, several agents of group I were, in the phenotypic classification of Marwitz (1990), considered to be distinct. The slight variation in the restriction pattern of the MLOs clustering with the stolbur isolate STOL may indicate the presence of a subgroup.

The AAY-, OAY- and SAY-MLOs, the three organisms of group I for which $16 \mathrm{~S}$ rDNA sequencing data are available, exhibit a sequence homology of at least $98.4 \%$. Therefore, they appear to be closely related although they belong to two different symptom groups. However, in their recent contribution on the significance of $16 \mathrm{~S}$ rRNA data for differentiation of prokaryotes, Fox et al. (1992) reported on bacteria which are distinguished at the species level despite an even higher degree of sequence homology than found in these three MLOs. The results 
of these authors indicate that a high 16S rDNA sequence similarity is not necessarily a sufficient criterion to guarantee species identity. To further differentiate the MLOs, especially those of the heterogeneous groups, additional tools such as other restriction endonucleases for $16 \mathrm{~S}$ rDNA analysis, specific genomic probes used in Southern hybridization, or serological methods must be applied. Monoclonal antibodies and polyclonal antisera proved to be highly specific and allowed the differentiation of, for instance, the AY- and the clover phyllody MLOs or even strains of the AY-MLO (Lin \& Chen, 1985; Clark et al., 1988).

The taxonomic distance of MLOs from different groups was also examined by comparing the $16 \mathrm{~S}$ rDNA sequencing data. Except for group II, which is closely related to group I, the homology is between 89.6 and $92.6 \%$. This is considerably lower than between the sequenced isolates of groups I or V. Despite the low number of organisms on which these figures are based, they indicate that the differences in the nucleotide sequence are expressed in the restriction patterns. These values also show a relatively close relationship between the MLOs examined, which may have arisen from a common ancestor. In other mollicutes, such as those of the genus Mycoplasma, the differences are considerably greater. For instance, the sequence homology of the $16 \mathrm{~S}$ rDNA of $M$. capricolum and $M$. hyopneumoniae is only $77.7 \%$ (Taschke et al., 1987). These two organisms were assigned to different phylogenetic groups by Weisburg $e t$ al. (1989).

This work was supported by grants from the Deutsche Forschungsgemeinschaft. We thank $H$. Kison and R. Mäurer for providing 16S rDNA sequencing data of the ULW-, ASHY- and ACLR-MLOs. We gratefully acknowledge L. Carraro, M. F. Clark, M. T. Cousin, F. Dosba and R. Marwitz for supplying sources of MLOs used in this study.

\section{References}

Ahrens, U. \& Seemüller, E. (1992). Detection of DNA of plant pathogenic mycoplasma-like organisms by a polymerase chain reaction that amplifies a sequence of the $16 \mathrm{~S}$ rRNA gene. Phytopathology 82, 828-832.

Ahrens, U., Seemüller, E. \& Lorenz, K. H. (1992). Genetic differentiation of the MLOs affecting temperate fruit trees. International Organisation for Mycoplasmology Letters 2, 150.

BertaccinI, A., Davis, R. E., \& LeE, I.-M. (1990). Distinction among mycoplasma-like organisms (MLOs) in Gladiolus, Ranunculus, Brassica, and Hydrangea through detection with nonradioactive cloned DNA probes. Phytopathologia mediterranea 29, 107-113.

Bonnet, F., Saillard, C., Kollar, A., Seemüller, E. \& Bovś, J. M. (1990). Detection and differentiation of the mycoplasma-like organism associated with apple proliferation disease using cloned DNA probes. Molecular Plant-Microbe Interactions 3, 438-443.

BovÉ, J. M. \& SaIllaRd, C. (1979). Cell biology of spiroplasmas. In The Mycoplasmas, vol. III, pp. 83-153. Edited by R. F. Whitcomb \& J. G. Tully. New York: Academic Press.

Bouvet, A., Grimont, F. \& Grimont, P. A. D. (1991). Intraspecific variations in nutritionally variant streptococci: rRNA gene restriction patterns in Streptococcus defectivus and Streptococcus adjacens. International Journal of Systematic Bacteriology 41, 483-486.

Carraro, L., Osler, R., Refatti, E. \& Poggi Pollini, C. (1988). Transmission of the possible agent of apple proliferation to Vinca rosea by dodder. Rivista di Patologia Vegetale S.IV, 43-52.

Clark, M. F., Davies, D. L., Buss, S. L., \& Morton, A. (1988). Serological discrimination among mycoplasma-like organisms using polyclonal and monoclonal antibodies. Acta Horticulturae 235, 107-113.

Davis, R. E., Sinclair, W. A., Lee, I.-M. \& Dally, E. L. (1992). Cloned DNA probes specific for detection of a mycoplasma-like organism associated with ash yellows. Molecular Plant-Microbe Interactions 5, 163-169.

Dijkstra, J. \& LEE, P. E. (1972). Transmission by dodder of sandal spike disease and the accompanying mycoplasma-like organisms via Vinca rosea. Netherlands Journal of Plant Pathology 78, 218-228.

Fox, G. E., WisotzkeY, J. D. \& JuRTSHUK, P. (1992). How close is close: $16 \mathrm{~S}$ rRNA sequence identity may not be sufficient to guarantee species identity. International Journal of Systematic Bacteriology $\mathbf{4 2}$, $166-170$.

Göbel, U. B, Geiser, A. \& Stanbridge, E. J. (1987). Oligonucleotide probes complementary to variable regions of ribosomal RNA discriminates between Mycoplasma species. Journal of General Microbiology 133, 1969-1974.

Grimont, F. \& GRIMONT, P. A. D. (1986). Ribosomal nucleic acid gene restriction patterns as potential taxonomic tools. Annales de l'Institut Pasteur/Microbiologie 137B, 165-175.

Gurtler, V., Wilson, V. A. \& MaYall, B. C. (1991). Classification of medically important clostridia using restriction endonuclease site differences of PCR-amplified 16S rDNA. Journal of General Microbiology 137, 2673-2679.

HeinTZ, W. (1989). Transmission of a new mycoplasma-like organism (MLO) from Cuscuta odorata (Ruiz et Pav.) to herbaceous plants and attempts to its elimination in the vector. Journal of Phytopathology 125, 171-186.

Higgins, D. G. \& Sharp, P. M. (1988). Clustal: a package for performing multiple alignments on a microcomputer. Gene $\mathbf{7 3}$, $237-244$.

JENSEN, D. D. (1956). Insect transmission of virus between tree and herbaceous plants. Virology 2, 249-260.

KLEIN, M. (1970). Safflower phyllody - a mycoplasma disease of Carthamus tinctorius in Israel. Plant Disease Reporter. 54, 735-738.

Kuske, C. R. \& KirkPatrick, B. C. (1992). Phylogenetic relationship between the western aster yellows mycoplasma-like organisms and other prokaryotes established by $16 \mathrm{~S}$ rRNA gene sequence. International Journal of Systematic Bacteriology 42, 226-233.

Kuske, C. R., KirkPatrick, B. C. \& Seemüller, E. (1991). Differentiation of virescence MLOs using western aster yellows mycoplasmalike organism chromosomal DNA probes and restriction fragment length polymorphism analysis. Journal of General Microbiology 137, 153-159.

Laigret, F., Grau, O. \& Bové, J. M. (1990). Comparison of 16S rDNA sequences of various mollicutes. Zentralblatt für Bakteriologie, Suppl. 20, 435-440.

Lane, D. J., Pace, B., Olsen, G. J., Stahl, D. A., Sogin, M. L. \& PACE, N. R. (1985). Rapid determination of 16S ribosomal RNA sequences for phylogenetic analysis. Proceedings of the National Academy of Sciences of the United States of America 82, 6955-6959.

LEE, L.-M. \& DAVIS, R. E. (1988). Detection and investigation of genetic relatedness among aster yellows and other mycoplasma-like organisms by using cloned DNA and RNA probes. Molecular Plant-Microbe Interactions 1, 303-310.

LeE I.-M., Davis R. E. \& DewitT N. (1990). Nonradioactive screening method for isolation of disease-specific probes to diagnose plant diseases caused by mycoplasma-like organisms. Applied Environmental Microbiology 56, 1471-1475.

Lim, P.-O. \& SEARS, B. B. (1989). 16S rRNA sequence indicates that plant-pathogenic mycoplasma-like organisms are evolutionarily distinct from animal mycoplasmas. Journal of Bacteriology 171, 5901-5906.

Lin, C.-P. \& ChEN, T. A. (1985). Monoclonal antibodies against the aster yellows agent. Science 227, 1233-1235. 
Maniatis, T., Fritsch, E. F. \& Sambrook, J. (1982). Molecular Cloning: a Laboratory Manual. Cold Spring Harbor, NY: Cold Spring Harbor Laboratory.

MaRChOUX,C. \& GiannotTI, J. (1971). Interférence entre deux mycoplasmas végétale. Physiologie Végétale 9, 595-610.

MarchuK, D., Drumm, M., Saulino, A. \& Collins F. S. (1991). Construction of T-vectors, a rapid and general system for direct cloning of unmodified PCR products. Nucleic Acids Research 19, 54.

MÄURER, R. \& SEEMÜLlER, E. (1992). Genetic relatedness of European and North American mycoplasma-like organisms from trees. International Organisation for Mycoplasmology Letters 2, 149.

MARWITZ, R. (1990). Diversity of yellows disease agents in plant infections. Zentralblatt für Bakteriologie, Suppl. 20, 431-434.

Marwitz, R. \& PeTzold, H. (1976). Elektronenmikroskopischer Nachweis mycoplasmaähnlicher Organismen in DelphiniumHybriden mit Blütenvergrünung und -verlaubung. Phytopathologische Zeitschrift 87, 1-11.

Marwitz, R. \& Petzold, H. (1983). Mykoplasmaähnliche Organismen als Krankheitserreger an Primeln. Gesunde Pflanze 35, 336-341.

MaRwitz, R., Petzold, H. \& Özel, M. (1974). Untersuchungen zur Übertragbarkeit des möglichen Erregers der Triebsucht des Apfels auf einen krautigen Wirt. Phytopathologische Zeitschrift 81, 85-91.

Marwitz, R., Petzold, H. \& Roth, L. (1979). Eine bisher unbekannte stolburverwandte Krankheit bei feldmäßig angebauten Pflanzen von Solanum marginatum in Ecuador. Phytopathologische Zeitschrift 95, 305-317.

Marwitz, R., Kuhbandner, B. \& Petzold, H. (1987). Übertragung mykoplasmaähnlicher Organismen (MLO) von hexenbesenkranken Heidelbeeren (Vaccinium myrtillus) auf Catharanthus roseus mit Hilfe von Cuscuta. Nachrichtenblatt der Deutschen Pflanzenschutzdienstes 39, 129-132.

McCoy, R. E., Caudwell, A., Chang, C. J., Chen, T. A., Chiykowski, I. N., Cousin, M. T., Dale, J. L., De LeeuW, G. T. N., Golino, D. A., HaCKett, K. J., KirkPa Trick, B. C., MarwitZ, R., Petzold, H., Sinha, R. C., Sugiura, M., Whitcomb, R. F., Young,
I. L., ZhU, B. M. \& SeEmüller, E. (1989). Plant diseases associated with mycoplasma-like organisms. In The Mycoplasmas, vol. V, pp.545-640. Edited by R. F. Whitcomb \& J. G. Tully. San Diego: Academic Press.

Moreno, P., Llacer, G., \& Medina, V. (1985). Descripcion y comparacion de varias micoplasmosis en Vinca rosea L. Anales del Instituto Nacional de Investigaciones Agrarias, Serie Agricola, N. Extr. 28, 287-309.

RAzIN, S. (1989). Molecular approach to mycoplasma phylogeny. In The Mycoplasmas, vol. V, pp. 33-69. Edited by R. F. Whitcomb \& J. G. Tully. San Diego: Academic Press.

Sears, B. B. \& Klomparens, K. L. (1989). Leaf tip cultures of the evening primrose allow stable, aseptic culture of mycoplasma-like organisms. Canadian Journal Plant Pathology 11, 343-348.

Sinclair, W. A., Braun, E. J. \& Larsen, A. O. (1976). Update on phloem necrosis of elms. Journal of Arboriculture 2, 106-113.

STACKEBRANDT, E. (1991). Unifying phylogeny and phenotypic diversity. In The Prokaryotes, vol I, pp. 19-47. Edited by A. Balows, H. G. Trüper, M. Dworkin, W. Harder, \& K.-H. Schleifer. New York: Springer Verlag.

Taschke, C., Ruland, K. \& Herrmann, R. (1987). Nucleotide sequence of the 16S rRNA of Mycoplasma hyopneumoniae. Nucleic Acids Research 15, 3918.

TaschKe, C., Wolters, J. \& Herrmann, R. (1990). Ribosomal RNA genes of four Mycoplasma species. Zentralblatt für Bakteriologie, Suppl. 20, 329-336.

Weisburg, W. G., Tully, J. G., Rose, D. L., Petzel, J. P., Oyaizu, H., Yang, D., Mandelco, L., Sechrest, J., LaWrence, T. G., VaN Etten, J., Maniloff, J. \& Woese, C. R. (1989). A phylogenetic analysis of the mycoplasmas: basis for their classification. Journal of Bacteriology 171, 6455-6467.

Weisburg, W. G., Barns, S. M., Pelletier, D. A. \& Lane, D. J. (1991). 16S ribosomal DNA amplification for phylogenetic study. Journal Bacteriology 173, 697-703.

Welvaert, W., Sakyn, G. \& Lagasse, A. (1975). Recherches sur les symptomes de la virescence chez l'Hydrangea macrophylla Thunb. Phytopathologische Zeitschrift 83, 152-158. 